\title{
The Influence Of Price, Product Quality And Brand Image On Purchase Decisions (Study At Nahdlatul Ulama University Students Of Surabaya UsingInk Brand Helmet)
}

\author{
Rachma Rizqina Mardhotillah ${ }^{1}$, Denis Fidita Karya ${ }^{1}$, Muhammad Ainur Rosyad ${ }^{1}$ \\ ${ }^{\text {I}}$ Faculty of Economics and Business, Universitas Nahdlatul Ulama Surabaya, Indonesia \\ *Corresponding Author: rachma.rizqina@unusa.ac.id
}

\begin{abstract}
Business competition in today's globalization era is very tight, where every company is required to be able to meet consumer needs and strive to create a product that has advantages and creates different products fromcompetitors. Data recorded according to the Central Bureau of Statistics (BPS) in 2014 - 2018. That the number of motorbikes has increased each year. With the increasing number of motorcycle users, there are also more helmet users and other accessories. This study aims to examine the effect of price, product quality, and brand image on purchasing decisions (a study on students of the Nahdlatul Ulama University Surabaya who used the INK brand helmet). In this study using quantitative research, which uses a research sample of 120 respondents. Using non-probability sampling method with purposive sampling approach and the method used in analyzing the data in this study using SmartPLS 3.0. Based on the results of the analysis and hypothesis testing on the data carried out, all variables obtained the result that the price had a positive effect on the purchase decision, while the product quality had a positive effect on the purchase decision, and the brand image did not have a positive effect on the purchase decision.
\end{abstract}

Keywords: Price, Product Quality, Brand Image And Purchase Decision

\section{INTRODUCTION}

Business competition in today's globalization era is very tight, in which every company is required to be able to meet consumer needs and strive to create a product that has advantages and creates a product that is different from its competitors. Different product development efforts can be an effective strategy for companies in providing innovative product offerings so that the satisfaction of each party is achieved, both from buyers for buying products that suit their needs and tastes as well as for companies who want to benefit from sales of its products and also maintain the company's good image in the eyes of customers.

Currently an interesting phenomenon in the motorcycle industry, it turns out that the automotive industry, especially motorcycles, has never known a crisis. Data recorded according to the Central Bureau of statistics (BPS) 2014-2018.

That the number of motorbikes in 2018 in Indonesia was $120,101,047$ units, an increase of $8,112,364$ units compared to the previous year. in 2017 there were $111,988,683$ units, also an increase of $6,838,601$ units compared to the previous year. In 2016 there were $105,150,082$ units, also an increase of $6,268,815$ units compared to the previous year. In 2015 there were $98,881,267$ units, also an increase of 5,905,027 units compared to the previous year. From the above figure shows that every year the number of motorbikes has increased.

A good helmet is a safe and comfortable helmet. Usually this kind of helmet passed the requirements of the Department of Transportation (DOT) or transportation standards in the United States. Apart from the Department of Transportation (DOT) there are also other 


\section{Procedia Business and Financial Technology}

Proceedings of the 2nd International Conference on Business and M anagement of T echnology (ICO N BM T 2020) - Part 2

standards such as in European countries, Japan and Indonesia which also have transportation standards with the label Indonesian National Standard (SNI).

Currently, there are many helmet brands offered to consumers who have Department of Transportation (DOT) requirements but have not met the Indonesian National Standard (SNI) in Indonesia. Where each helmet brand seeks to make its product superior to other brands, in good and proper marketing activities, namely by having an important role in supporting business continuity and development within a company. In other words, the producer must be able to attract consumers' interest in the products they sell and strive to satisfy the needs of their consumers. [1].

Based on the data above, in 2020 the INK brand helmet has decreased by $18.7 \%$ in the number two top brand after the KYT brand helmet compared to the previous year in 2019 INK has increased by $19.6 \%$ until the previous year in 2018 INK helmets did not increase still at $19.6 \%$. Compared to 2017, the INK helmet has increased by the amount of $21.7 \%$, compared to 2016 experienced a decline of $17.6 \%$. So with this, the INK helmet from year to year experiences instability in the segment of consumer interest in purchasing INK helmets.

This research was conducted with the aim of knowing the influence of price, product quality, and product image which is the choice of Nahdlatul Ulama University students in Surabaya compared to other helmet brands and will influence consumer purchasing decisions.

\section{METHODOLOGY}

This type of research is quantitative research. According to Sugiyo [2], the quantitative research method can be interpreted as a research method based on the philosophy of positivism, used to research on certain populations or samples. It is called a quantitative method because the research data is in the formof numbers and the analysis uses statistics. In this study, the population used was 1825 year old students who use INK helmets who live at Nahdlatul Ulama University, Surabaya. Data management in this study will use smartPLS 3.0 Structural Equation Modeling (SEM) software is a method used to cover weaknesses in the regression method. According to experts, the Structural Equation Modeling (SEM) research method is grouped into two approaches, namely the Covariance Based SEM (CBSEM) approach and Variance Based SEM or Partial Least Square (PLS).

These are 3 Hypotheses in this research:

Hypothesis 1: Price has a positive effect on purchasing decisions.

Hypothesis 2: Product quality has a positive effect on purchasing decisions.
Hypothesis 3: Brand image has no positive effect on purchasing decisions.

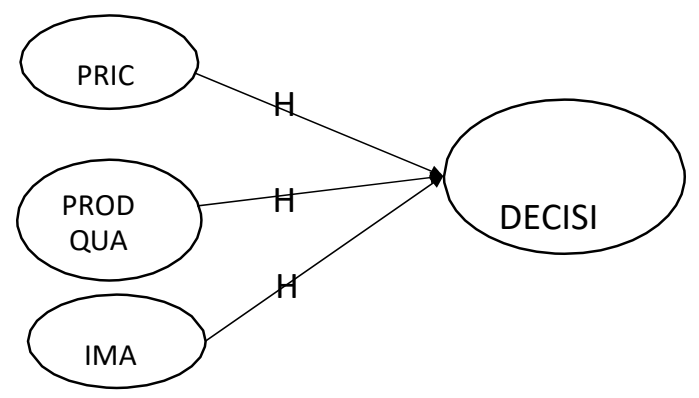

\section{RESULT AND CONCLUSION}

After processing the data, the results of the processing can be used to answer the hypothesis in this study. Hypothesis testing in this study was carried out by looking at the TStatistic value and the P- Value value. The research hypothesis can be stated as accepted if the P-Value value is $<0.05$ [3].

\begin{tabular}{|c|c|c|c|}
\hline $\begin{array}{c}\text { Hypothes } \\
\text { es }\end{array}$ & $\begin{array}{c}\text { T- } \\
\text { Statisti } \\
\text { c }\end{array}$ & $\begin{array}{c}\text { P- } \\
\text { Value } \\
\text { s }\end{array}$ & Result \\
\hline H1 & 3,184 & $\begin{array}{c}0,00 \\
2\end{array}$ & $\begin{array}{c}\text { Accepte } \\
\text { d }\end{array}$ \\
\hline H2 & 2,338 & $\begin{array}{c}0,02 \\
0\end{array}$ & $\begin{array}{c}\text { Accepte } \\
\text { d }\end{array}$ \\
\hline H3 & 0,087 & $\begin{array}{c}0,93 \\
1\end{array}$ & $\begin{array}{c}\text { Not } \\
\text { Accepte } \\
\text { d }\end{array}$
\end{tabular}

Based on the results of the data in table above, it can be seen that the hypothesis that has a significant effect is $\mathrm{H} 1$ and $\mathrm{H} 2$, while the hypothesis that does not have a significant effect is H3. The following is an explanation of each hypothesis.

Hypothesis 1: price has a positive effect on pre-purchase decisions, according to the table data above, the P-Valeus result is 0.002 . Which means that the hypothesis is accepted

Hypothesis 2: product quality has a positive effect on purchasing decisions, according to the data table above shows the P-Valeus result of 0.020 . Which means that the hypothesis is accepted.

Hypothesis 3: brand image has no positive effect on the purchase decision, according to the data table above shows the P-Valeus result of 0.931 . Which means that the hypothesis is notaccepted. 


\section{Procedia Business and Financial Technology}

Proceedings of the 2 nd International Conference on Business and M anagement of T echnology (ICON BM T 2020) - Part 2

\section{REFERENCES}

[1] "Top brand award.2020.top brand index kategori lengkap. diakses dari https://www.topbrandaward.com/top-brand-index/," Pada tanggal, Jun. 2020.
[2] Sugiyono, Metode Penelitian Kuantitatif Kualitatif dan $R \& D$. Bandung: Alfabeta, 2012.

[3] S. Y. Heri Kurniawan, Generasi Baru Mengolah Data Penelitian dengan Partial least Square Path Modeling. Jakarta: Salemba Empat, 2011. 